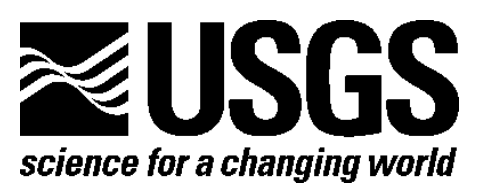

Prepared in cooperation with the U.S. Army Corps of Engineers

\title{
An Evaluation of the Accuracy of Modeled and Computed Streamflow Time-Series Data for the Ohio River at Hannibal Lock and Dam and at a Location Upstream From Sardis, Ohio
}

By G.F. Koltun

Open-File Report 2015-1058

U.S. Department of the Interior

U.S. Geological Survey 


\section{U.S. Department of the Interior \\ SALLY JEWELL, Secretary}

\section{U.S. Geological Survey \\ Suzette M. Kimball, Acting Director}

U.S. Geological Survey, Reston, Virginia: 2015

For more information on the USGS—-the Federal source for science about the Earth, its natural and living resources, natural hazards, and the environment-visit http://www.usgs.gov or call 1-888-ASK-USGS (1-888-275-8747)

For an overview of USGS information products, including maps, imagery, and publications, visit http://www.usgs.gov/pubprod

To order this and other USGS information products, visit http://store.usgs.gov

Any use of trade, firm, or product names is for descriptive purposes only and does not imply endorsement by the U.S. Government.

Although this information product, for the most part, is in the public domain, it also may contain copyrighted materials as noted in the text. Permission to reproduce copyrighted items must be secured from the copyright owner.

Suggested citation:

Koltun, G.F., 2015, An evaluation of the accuracy of modeled and computed streamflow time-series data for the Ohio River at Hannibal Lock and Dam and at a location upstream from Sardis, Ohio: U.S. Geological Survey Open-File Report 2015-1058, 23 p., http://dx.doi.org/10.3133/ofr20151058.

ISSN 2331-1258 (online) 


\section{Acknowledgments}

The author wishes to thank and acknowledge the U.S. Army Corps of Engineers and National Weather Service for participating in this study and providing some of the modeled/computed streamflow timeseries data described in this report. Thanks also are extended to the U.S. Geological Survey (USGS) West Virginia Water Science Center personnel who made special efforts to obtain the streamflow measurements used in this analysis in a timely fashion and to David S. Mueller (USGS, Office of Surface Water) and Branden L. VonIns (USGS, Ohio Water Science Center) for their assistance with compiling and (or) evaluating the measurements. 



\section{Contents}

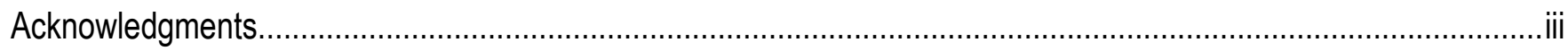

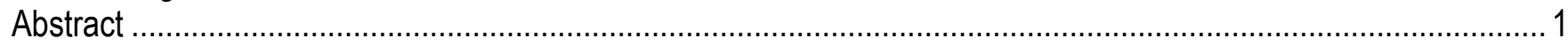

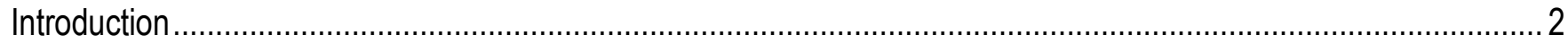

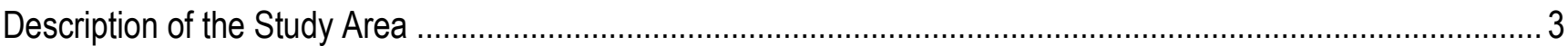

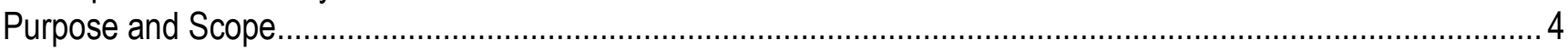

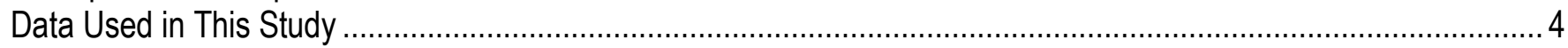

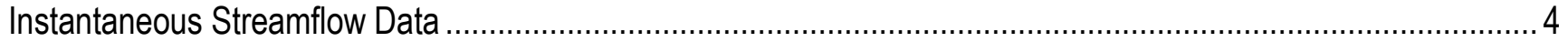

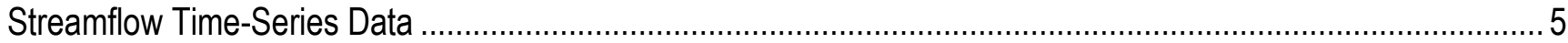

Ohio River Near USGS Streamgage 03114306, Upstream From Sardis, Ohio ............................................ 6

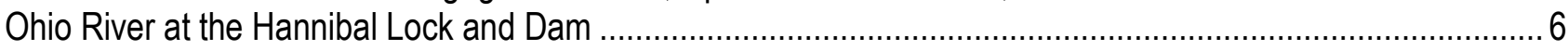

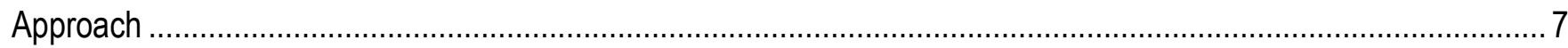

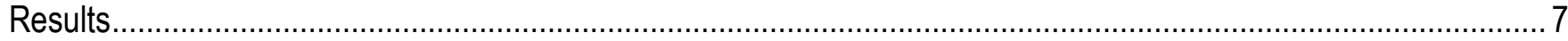

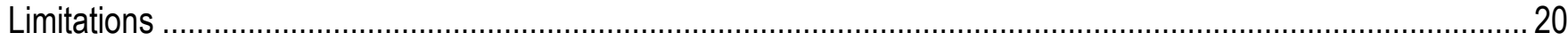

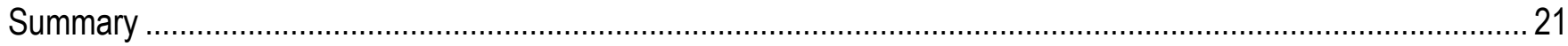

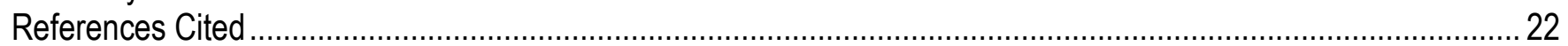




\section{Figures}

Figure 1. Study reach on the Ohio River and approximate locations where streamflow measurements were made.

Figure 2. Boxplots and data plots (binned data, arbitrary horizontal offset) showing the distribution of instantaneous streamflows measured and computed for the Ohio River above Sardis, Ohio (streamgage number 03114306), July 1, 2013, to June 30, 2014.

Figure 3. Scatterplot of USGS measured streamflows and corresponding streamflows interpolated from 15-minute streamflow time series computed for the USGS streamgage on the Ohio River above Sardis, Ohio (station number 03114306).....

Figure 4. Scatterplot of USGS measured streamflows and corresponding streamflows interpolated from USACE modeled 12 UTC streamflow time series for Ohio River mile 129.5 near the USGS streamgage on the Ohio River above Sardis, Ohio (station number 03114306).

Figure 5. Scatterplot of USGS measured streamflows for the Ohio River approximately 1.5 miles downstream from Hannibal Lock and Dam and corresponding traveltime-corrected streamflows interpolated from NWS 6-hour modeled streamflow time series for the Ohio River at Hannibal Lock and Dam.

Figure 6. Scatterplot of USGS measured streamflows for the Ohio River approximately 1.5 miles downstream from Hannibal Lock and Dam and corresponding traveltime-corrected streamflows interpolated from USACE 1-hour modeled streamflow time series for the Ohio River at Hannibal Lock and Dam.

Figure 7. Scatterplot of USGS measured streamflows for the Ohio River approximately 1.5 miles downstream from Hannibal Lock and Dam and corresponding traveltime-corrected streamflows interpolated from USACE 1-hour streamflow time series determined from gate-opening ratings and hydropower releases for the Ohio River at Hannibal Lock and Dam

Figure 8. Scatterplot of streamflows measured at the Sardis gage versus the residuals for the corresponding interpolated modeled/computed time-series streamflows expressed as a percentage of the measured streamflows

Figure 9. Scatterplot of streamflows measured at the Hannibal Lock and Dam measurement location versus the residuals for the corresponding traveltime-corrected interpolated modeled/computed time-series streamflows expressed as a percentage of the measured streamflows.

Figure 10. Modeled/computed streamflow hydrographs for the Ohio River above Sardis, Ohio (station number 03114306), July 1, 2013, to June 30, 2014.

Figure 11. Modeled/computed streamflow hydrographs for the Ohio River at Hannibal Lock and Dam, July 1,2013 , to June 30,2014 


\section{Tables}

Table 1. Summary of streamflow measurement data for the Ohio River about 1.5 miles downstream from Hannibal Lock and Dam and near USGS streamgage number 03114306, upstream from Sardis, Ohio

Table 2. Streamflow measurement results and corresponding time-series-interpolated streamflow results for the Ohio River near USGS streamgage number 03114306, upstream from Sardis, Ohio.

Table 3. Streamflow measurement results and corresponding traveltime-corrected time-seriesinterpolated streamflow results for the Ohio River about 1.5 miles downstream from Hannibal Lock and Dam.

Table 4. Summary and rankings of root-mean-square errors and mean absolute residuals for streamflows interpolated from modeled and computed streamflow time series. 


\section{Conversion Factors}

Inch/Pound to International System of Units

\begin{tabular}{|c|c|c|}
\hline Multiply & By & To obtain \\
\hline \multicolumn{3}{|c|}{ Length } \\
\hline foot $(\mathrm{ft})$ & 0.3048 & meter $(\mathrm{m})$ \\
\hline mile (mi) & 1.609 & kilometer $(\mathrm{km})$ \\
\hline \multicolumn{3}{|c|}{ Area } \\
\hline square feet $\left(\mathrm{ft}^{2}\right)$ & 0.09290 & square meters $\left(\mathrm{m}^{2}\right)$ \\
\hline square mile $\left(\mathrm{mi}^{2}\right)$ & 2.590 & square kilometer $\left(\mathrm{km}^{2}\right)$ \\
\hline \multicolumn{3}{|c|}{ Volume } \\
\hline cubic foot $\left(\mathrm{ft}^{3}\right)$ & 0.02832 & cubic meter $\left(\mathrm{m}^{3}\right)$ \\
\hline \multicolumn{3}{|c|}{ Flow rate } \\
\hline cubic foot per second $\left(\mathrm{ft}^{3} / \mathrm{s}\right)$ & 0.02832 & cubic meter per second $\left(\mathrm{m}^{3} / \mathrm{s}\right)$ \\
\hline
\end{tabular}

\section{Abbreviations}

$\begin{array}{ll}\text { ADCP } & \text { acoustic Doppler current profiler } \\ \text { ADVM } & \text { acoustic Doppler velocity meter } \\ \text { MHz } & \text { megahertz } \\ \text { NWS } & \text { National Weather Service } \\ \text { PR } & \text { residual, expressed as percentage of measured streamflow } \\ \text { RMSE } & \text { root-mean-square error } \\ \text { SAC-SMA } & \text { Sacramento Soil Moisture Accounting Model } \\ \text { USACE } & \text { U.S. Army Corps of Engineers } \\ \text { USGS } & \text { U.S. Geological Survey } \\ \text { UTC } & \text { Coordinated Universal Time }\end{array}$




\title{
An Evaluation of the Accuracy of Modeled and Computed Streamflow Time-Series Data for the Ohio River at Hannibal Lock and Dam and at a Location Upstream From Sardis, Ohio
}

By G.F. Koltun

\begin{abstract}
Between July 2013 and June 2014, the U.S. Geological Survey (USGS) made 10 streamflow measurements on the Ohio River about 1.5 miles (mi) downstream from the Hannibal Lock and Dam (near Hannibal, Ohio) and 11 streamflow measurements near the USGS Sardis gage (station number 03114306) located approximately $2.4 \mathrm{mi}$ upstream from Sardis, Ohio. The measurement results were used to assess the accuracy of modeled or computed instantaneous streamflow time series created and supplied by the USGS, U.S. Army Corps of Engineers (USACE), and National Weather Service (NWS) for the Ohio River at Hannibal Lock and Dam and (or) at the USGS streamgage. Hydraulic or hydrologic models were used to create the modeled time series; index-velocity methods or gate-opening ratings coupled with hydropower operation data were used to create the computed time series. The time step of the various instantaneous streamflow time series ranged from 15 minutes to 24 hours (once-daily values at 12:00 Coordinated Universal Time [UTC]). The 15-minute time-series data, computed by the USGS for the Sardis gage, also were downsampled to 1-hour and 24-hour time steps to permit more direct comparisons with other streamflow time series.

To facilitate comparisons between measurement results and time-series data, streamflows corresponding to the times of the streamflow measurements were computed from the time-series data by time-based linear interpolation. Prior to doing interpolations, measurement times for the Hannibal Lock and Dam location were adjusted for traveltime to account for the fact that the streamflow measurements were made about $1.5 \mathrm{mi}$ downstream from the location corresponding to the modeled/computed timeseries data. Measured and interpolated streamflows were tabulated along with residuals (the difference between measured and interpolated streamflows) and selected summary statistics.

Overall, streamflows interpolated from the USGS computed 15-minute time-series data (hereafter referred to as the USGS 15-minute time-series data) had the smallest root-mean-square error (RMSE) $\left(3,939\right.$ cubic feet per second $\left.\left[\mathrm{ft}^{3} / \mathrm{s}\right]\right)$ and the second smallest mean absolute residual $\left(2,636 \mathrm{ft}^{3} / \mathrm{s}\right)$, whereas streamflows interpolated from the USACE 12 UTC time series had the largest $\operatorname{RMSE}\left(14,590 \mathrm{ft}^{3} / \mathrm{s}\right)$ and the largest mean absolute residual $\left(10,800 \mathrm{ft}^{3} / \mathrm{s}\right)$. The larger RMSEs for streamflows interpolated from the USACE 12 UTC time series likely resulted in part from the coarser time step of that time series. Streamflows interpolated from the USGS downsampled 1-hour time series had the second smallest RMSE $\left(4,025 \mathrm{ft}^{3} / \mathrm{s}\right)$ and the smallest mean absolute residual $\left(2,600 \mathrm{ft}^{3} / \mathrm{s}\right)$. Somewhat surprisingly, streamflows interpolated from the NWS 6-hour model time series had the third
\end{abstract}


smallest RMSE $\left(4,483 \mathrm{ft}^{3} / \mathrm{s}\right)$ and mean absolute residual $\left(4,050 \mathrm{ft}^{3} / \mathrm{s}\right)$ in spite of being determined from a time series with a coarser time step than the USACE 1-hour modeled and computed time series.

Measured streamflows at the Sardis gage and at the Hannibal Lock and Dam measurement location were plotted versus residuals (expressed as a percentage of the measured streamflows) of corresponding interpolated time-series streamflow values. Results for each of the time series exhibited some anomaly, possibly indicating the need and (or) potential for improvement in the streamflow computational/modeling processes.

Streamflow hydrographs were plotted for modeled/computed time series for the Ohio River near the USGS Sardis gage and the Ohio River at the Hannibal Lock and Dam. In general, the time series at these two locations compared well. Some notable differences include the exclusive presence of short periods of negative streamflows in the USGS 15-minute time-series data for the gage on the Ohio River above Sardis, Ohio, and the occurrence of several peak streamflows in the USACE gate/hydropower time series for the Hannibal Lock and Dam that were appreciably larger than corresponding peaks in the other time series, including those modeled/computed for the downstream Sardis gage.

\section{Introduction}

The Ohio River is one of the largest rivers in the United States, stretching about 981 miles (mi) from Pittsburgh, Pennsylvania, to Cairo, Illinois, and it is the largest tributary by volume to the Mississippi River. The river has been heavily modified to support inland navigation, with a current (January 1, 2015) system of 20 locks and dams managed by the U.S. Army Corps of Engineers (USACE). More than 25 million people - about 8 percent of the U.S. population - live in the Ohio River Basin (Ohio River Valley Sanitation Commission [ORSANCO], 2014). In spite of its size and importance as a source of water and navigation, there is relatively little validated historical streamflow information available for the Ohio River; there are only five current U.S. Geological Survey (USGS) gages on the Ohio River where near real-time streamflow time series are reported. Two of the gages (Ohio River above Sardis, OH [03114306]; and Ohio River at Old Shawneetown, IL-KY [03381700]) use side-looking acoustic Doppler velocity meter (ADVM) technology to measure index velocities, which in turn are used to compute streamflows. The other three gages (Ohio River at Sewickley, PA [03086000]; Ohio River at Louisville, KY [03294500]; and Ohio River at Metropolis, IL [03611500]) use stage- or fall-based methods to compute streamflows.

Both the USACE and the National Weather Service (NWS) compute streamflows for selected locations on the Ohio River to meet their individual program objectives. The USACE computes streamflows at locks and dams on the basis of gate-opening ratings and operation of hydroelectric facilities and (or) by means of a one-dimensional unsteady-flow hydraulic model. The NWS computes streamflows by using a hydrologic model.

Although there are multiple sources of computed streamflow data for the Ohio River, there have been few opportunities to validate those data against independent streamflow measurements (that is, measurements that have not been used to calibrate the streamflow-computation procedures).

Consequently, the USGS, in cooperation with the USACE, undertook a study to collect independent streamflow measurements at two locations on the Ohio River to facilitate comparisons with streamflows modeled/computed by the USGS, USACE, and NWS. 


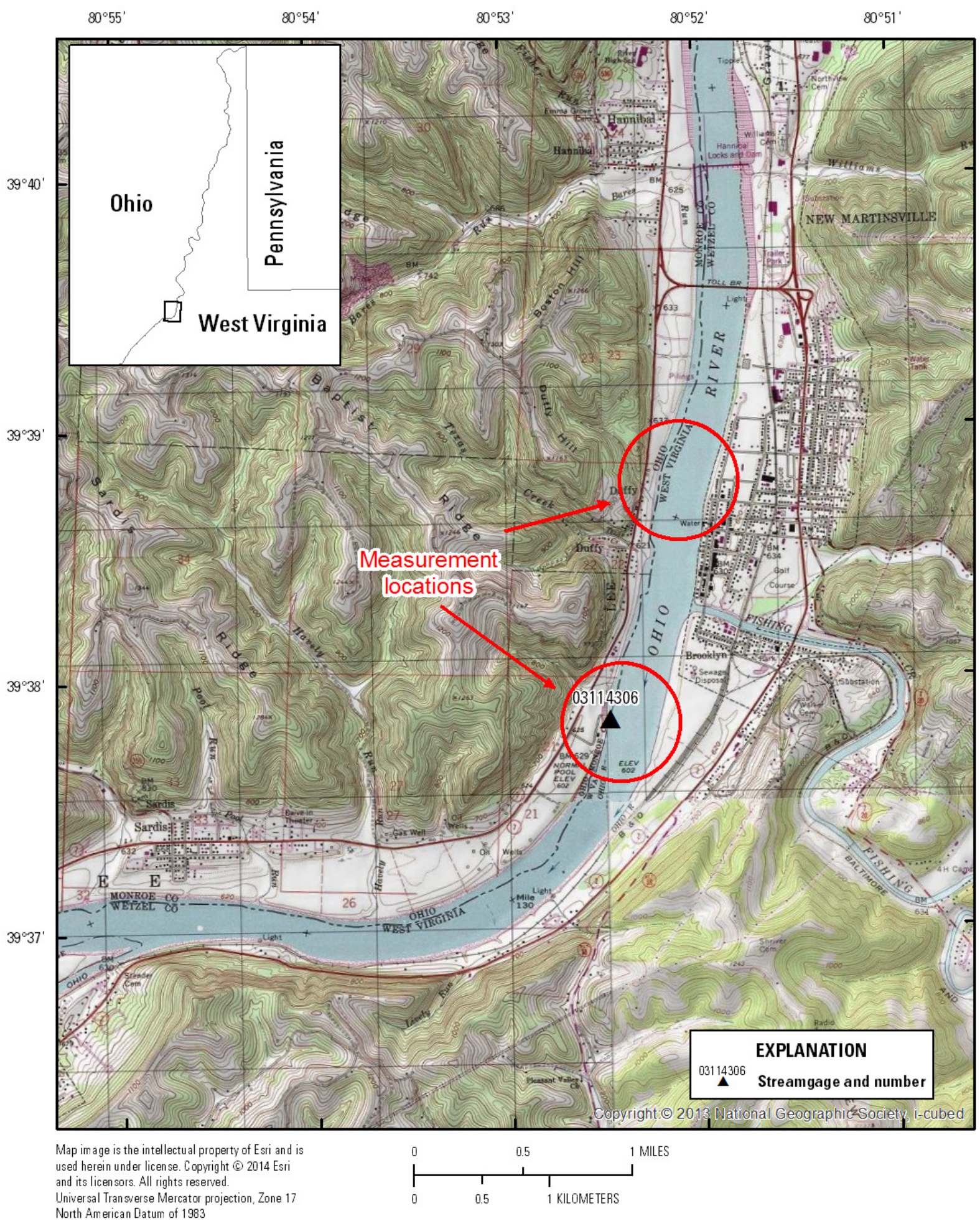

Figure 1. Study reach on the Ohio River and approximate locations where streamflow measurements were made. 


\section{Description of the Study Area}

Streamflow measurements were made by the USGS near the upstream and downstream ends of a reach of the Ohio River extending from about $1.5 \mathrm{mi}$ downstream from the Hannibal Lock and Dam, near Hannibal, Ohio, to the USGS streamgage (station number 03114306) on the Ohio River, located approximately 2.4 mi upstream from Sardis, Ohio, and 2.6 mi downstream from the Hannibal Lock and Dam (Figure 1). The drainage areas of the Ohio River just downstream from the Hannibal Lock and Dam and at the USGS gage on the Ohio River above Sardis, Ohio, are 25,930 square miles $\left(\mathrm{mi}^{2}\right)$ and $26,156 \mathrm{mi}^{2}$, respectively. Fishing Creek discharges to the Ohio River from the east between the upstream and downstream measurement locations, accounting for about 220 of the $226-\mathrm{mi}^{2}$ difference in drainage areas.

\section{Purpose and Scope}

The primary purpose of this report is to provide an assessment of the accuracy of modeled/computed streamflow time series created by the USGS, USACE, and NWS for the Ohio River downstream from the Hannibal Lock and Dam and (or) at the streamflow gage on the Ohio River above Sardis, Ohio. A secondary purpose is to compare and contrast streamflow time series created by the three agencies. This report summarizes results for the period July 1, 2013, to June 30, 2014.

\section{Data Used in This Study}

The following sections describe the instantaneous streamflow and streamflow time-series data used in this study.

\section{Instantaneous Streamflow Data}

To help evaluate the accuracy of streamflow time series created by the USGS, USACE, and NWS, the USGS made 10 to 11 streamflow measurements at each of 2 locations on the Ohio River between July 23, 2013, and June 3, 2014 (Table 1). Measurements were made over a broad range of streamflows about 1.5 mi downstream from the Hannibal Lock and Dam (hereafter referred to as the Hannibal Lock and Dam location) and near the USGS streamflow gage number 03114306 on the Ohio River upstream from Sardis, Ohio (hereafter referred to as the Sardis gage location). Moving-boat measurements were made by hydrologic technicians from the USGS West Virginia Water Science Center by means of an acoustic Doppler current profiler (ADCP), using methods described by Mueller and others (2013). Prior to preparation of this report, measurement results were not made available to the USGS Pennsylvania Water Science Center (who operates the Sardis gage) or to the USACE or NWS.

SonTek RiverSurveyor model M9 (RS-M9) ADCPs were used to make all streamflow measurements. The RS-M9s have nine transducers: one vertical-beam transducer that operates at 0.5 megahertz $(\mathrm{MHz})$ and dual 4-beam transducers (in a Janus configuration with a 25-degree slant angle) that operate at $3 \mathrm{MHz}$ and $1 \mathrm{MHz}$. All streamflow measurements consisted of 2 channel transects (one moving from right to left and one moving from left to right) having a total exposure time of 12 minutes or greater. 
Table 1. Summary of streamflow measurement data for the Ohio River about 1.5 miles downstream from Hannibal Lock and Dam and near USGS streamgage number 03114306, upstream from Sardis, Ohio.

[UTC, Coordinated Universal Time; $\mathrm{ft}$, feet; $\mathrm{ft}^{2}$, square feet; $\mathrm{ft}^{3} / \mathrm{s}$, cubic feet per second; G, good; F, fair; P, poor; -, no data]

\begin{tabular}{|c|c|c|c|c|c|c|c|c|c|c|c|c|c|c|}
\hline \multirow[b]{2}{*}{ Date } & \multicolumn{7}{|c|}{$\begin{array}{l}\text { Ohio River near USGS streamgage } 03114306 \text { upstream from } \\
\text { Sardis, Ohio }\end{array}$} & \multicolumn{7}{|c|}{$\begin{array}{c}\text { Ohio River about } 1.5 \text { miles downstream from the } \\
\text { Hannibal Lock and Dam }\end{array}$} \\
\hline & UTC & $\begin{array}{l}\text { Measured } \\
\text { streamflow } \\
\left(\mathrm{ft}^{3} / \mathrm{s}\right)\end{array}$ & $\begin{array}{c}\text { Standard } \\
\text { deviation } \\
\left(\mathrm{ft}^{3} / \mathrm{s}\right)\end{array}$ & $\begin{array}{c}\text { Mean } \\
\text { velocity } \\
(\mathrm{ft} / \mathrm{s})\end{array}$ & $\begin{array}{l}\text { Channel } \\
\text { width } \\
\text { (ft) }\end{array}$ & $\begin{array}{c}\text { Channel } \\
\text { area } \\
\left(\mathrm{ft}^{2}\right)\end{array}$ & Rated & UTC & $\begin{array}{l}\text { Measured } \\
\text { streamflow } \\
\left(\mathrm{ft}^{3} / \mathrm{s}\right)\end{array}$ & $\begin{array}{c}\text { Standard } \\
\text { deviation } \\
\left(\mathrm{ft}^{3} / \mathrm{s}\right)\end{array}$ & $\begin{array}{c}\text { Mean } \\
\text { velocity } \\
(\mathrm{ft} / \mathrm{s})\end{array}$ & $\begin{array}{l}\text { Channel } \\
\text { width } \\
\text { (ft) }\end{array}$ & $\begin{array}{c}\text { Channel } \\
\text { area } \\
\left(\mathrm{ft}^{2}\right)\end{array}$ & Rated \\
\hline $07 / 23 / 2013$ & $20: 28$ & 34,800 & 1,998 & 1.40 & 1,250 & 24,900 & $\mathrm{P}$ & $19: 29$ & 36,400 & 1,117 & 1.71 & 1,270 & 21,300 & $\mathrm{P}$ \\
\hline $11 / 15 / 2013$ & $17: 53$ & 26,900 & 58 & 1.20 & 1,280 & 22,400 & G & $18: 56$ & 27,200 & 115 & 1.31 & 1,280 & 20,800 & $\mathrm{~F}$ \\
\hline $12 / 03 / 2013$ & $18: 07$ & 44,000 & 2,360 & 1.77 & 1,200 & 24,900 & $\mathrm{P}$ & $13: 37$ & 47,800 & 1,058 & 2.06 & 1,270 & 23,200 & $\mathrm{P}$ \\
\hline $02 / 21 / 2014$ & $17: 31$ & 96,800 & 2,149 & 3.47 & 1,270 & 27,900 & $\mathrm{G} / \mathrm{F}$ & - & - & - & - & - & - & - \\
\hline 03/26/2014 & $15: 46$ & 37,600 & 82 & 1.65 & 1,250 & 22,900 & G & $15: 10$ & 38,400 & 477 & 1.82 & 1,270 & 21,100 & $\mathrm{G} / \mathrm{F}$ \\
\hline 04/09/2014 & $15: 48$ & 87,100 & 739 & 3.01 & 1,230 & 28,900 & $\mathrm{G} / \mathrm{F}$ & $16: 33$ & 86,000 & 1,335 & 3.45 & 1,250 & 24,900 & $\mathrm{~F}$ \\
\hline $04 / 24 / 2014$ & $15: 24$ & 32,900 & 261 & 1.31 & 1,270 & 25,100 & $\mathrm{~F}$ & $15: 57$ & 33,900 & 381 & 1.58 & 1,300 & 21,500 & $\mathrm{~F}$ \\
\hline 05/01/2014 & $17: 21$ & 82,600 & 3,501 & 2.92 & 1,270 & 28,300 & G & $16: 53$ & 81,400 & 200 & 3.55 & 1,220 & 23,000 & $\mathrm{~F} / \mathrm{P}$ \\
\hline 05/16/2014 & $18: 06$ & 143,000 & 1,630 & 4.43 & 1,340 & 32,300 & $\mathrm{~F} / \mathrm{P}$ & $17: 36$ & 142,100 & 416 & 4.97 & 1,360 & 28,600 & G \\
\hline $05 / 27 / 2014$ & $17: 04$ & 59,800 & 70 & 2.44 & 1,280 & 24,500 & G & $16: 38$ & 60,000 & 417 & 2.68 & 1,300 & 22,300 & $\mathrm{~F}$ \\
\hline $06 / 03 / 2014$ & $16: 44$ & 28,500 & 577 & 1.27 & 1,250 & 22,400 & $\mathrm{P}$ & $16: 18$ & 29,000 & 188 & 1.38 & 1,280 & 21,000 & F \\
\hline
\end{tabular}




\section{Streamflow Time-Series Data}

Modeled and (or) computed Ohio River streamflow time-series data were obtained from the USGS, USACE, and NWS for the time period from July 1, 2013, to June 30, 2014. Time-series data for the downstream (Sardis gage) location were available only from the USGS, and USACE and time-series data for the upstream (Hannibal Lock and Dam) location were available only from the USACE and NWS.

\section{Ohio River Near USGS Streamgage 03114306, Upstream From Sardis, Ohio}

Fifteen-minute-interval instantaneous streamflow time-series data for the Sardis gage were retrieved from the USGS National Water Information System (NWIS) Web page (http://waterdata.usgs.gov/nwis/uv/?site_no=03114306\&agency_cd=USGS, accessed November 10, 2014). USGS streamflow time-series data for the Sardis gage were computed by means of the indexvelocity method (Levesque and Oberg, 2012). The data available on the Web had gaps in the record, including one gap from October 23 to November 4, 2013, when the ADVM failed and had to be replaced, and gaps on November 15, 2013; November 18-20, 2013, and January 18-29, 2014 that were caused by power issues (Jamie McCoy, USGS Pennsylvania Water Science Center, written commun., 2014). Some time-series data for July 23, 2013, and November 15, 2013, that were not available on the Web were subsequently provided by the USGS Pennsylvania Water Science Center (Elizabeth Hittle, USGS Pennsylvania Water Science Center, written commun, 2014).

The USACE provided a time series of once-daily instantaneous streamflows for a location near the USGS Sardis gage, reported at 12:00 UTC (Brian Astifan, USACE, unpub. data, 2014). According to Brian Astifan (written commun., 2014), the USACE used the one-dimensional unsteady-flow model called Cascade to compute streamflows at river mile 129.5 on the Ohio River near the Sardis gage. Cascade is a fully implicit model that uses finite-difference approximations of the one-dimensional Saint-Venant differential equations for the conservation of mass and momentum (Lee and Wisbith, 2006).

\section{Ohio River at the Hannibal Lock and Dam}

The NWS provided modeled streamflow data at a 6-hour time step for the Ohio River at the Hannibal Lock and Dam. The NWS used the Sacramento Soil Moisture Accounting (SAC-SMA) model (Burnash, 1995; NWS, 2014a) with observed temperature and precipitation data along with unit hydrographs to compute runoff from basins with drainage areas ranging from 13 to $732 \mathrm{mi}^{2}$ (Raymond Davis, NWS, written commun., 2015). The modeled streamflows were corrected to calculated streamflows at USGS gage locations; however, no corrections were made for streamflows reported at gage sites on the Ohio River itself. Streamflow contributions from Ohio River tributaries were added to Ohio River mainstem streamflows and then routed downstream by means of lag and K routing (NWS, 2014b) and Tatum coefficient routing (NWS, 2015).

The USACE provided two hourly time series of instantaneous streamflows for the Hannibal Lock and Dam (Brian Astifan, USACE, unpub. data, 2014). The first time series consisted of streamflow data computed with the Cascade model. The second time series was computed from gateopening ratings and reported hydropower streamflows (Brian Astifan, USACE, written commun., 2014). 


\section{Approach}

Streamflow measurements made by the USGS were assigned a time equal to the midpoint between the start and end times of the measurement. In order to facilitate comparisons between measurement results and time-series data, streamflows corresponding to the times of the streamflow measurements were computed from the time-series data by interpolating linearly in time between timeseries values that bracketed the times of measurements. So, for example, if a streamflow measurement was made at 10:30 UTC and streamflow time-series values of 40,000 and 42,000 cubic feet per second $\left(\mathrm{ft}^{3} / \mathrm{s}\right)$ were reported for 10:00 and 11:00 UTC, respectively, then the interpolated streamflow at the midpoint in time (10:30 UTC) would be $41,000 \mathrm{ft}^{3} / \mathrm{s}$.

As previously stated, the Hannibal Lock and Dam measurement location was about $1.5 \mathrm{mi}$ downstream from the Hannibal Lock and Dam. There is only about a 0.02 percent increase in drainage area between the lock and dam and the measurement location, suggesting that any change in streamflow between the two locations would likely be much smaller than measurement error and could therefore be ignored; however, the potential effects of streamflow traveltime between the lock and dam and the measurement location could be more substantial. In order to account for traveltime effects for the purposes of interpolation, the measurement time was offset by subtracting the time it would take for a particle of water moving at the mean velocity associated with the measurement to travel the approximately $1.5 \mathrm{mi}$ distance between the Hannibal Lock and Dam and the measurement location. This assumes that the mean velocity was constant in the $1.5-\mathrm{mi}$ reach and did not change over the duration of the traveltime. It also assumes that the traveltime is better approximated by the traveltime of a particle of water as opposed to the traveltime of a flood wave. Although these assumptions may not be consistently true, it is likely that the offset time more accurately reflects the effective model time corresponding to the measured streamflows than the actual measurement time.

Each streamflow measurement consisted of two channel transects for which streamflows were individually computed and then averaged. The standard deviation of the streamflows for the two transects was computed and used to compute an ad hoc indicator of uncertainty for the measurement. The indicator of uncertainty is represented in scatterplots by bars that extend \pm 2 standard deviations from the reported streamflow value.

\section{Results}

Streamflow measurement and interpolated streamflow time-series results for the Sardis gage and the Hannibal Lock and Dam locations are listed in Table 2 and Table 3, respectively. In addition to the measured and interpolated streamflows, residuals (the measured streamflows minus the

modeled/computed streamflows) are reported both in cubic feet per second $\left(\mathrm{ft}^{3} / \mathrm{s}\right)$ and as a percentage of the measured streamflows. Positive residuals indicate that the modeled/computed value was less than the measured value; negative residuals indicate that the modeled/computed value was greater than the measured value. Maximum, minimum, mean, median, and mean of interpolated streamflows and residuals are listed in the tables below the measurement results. 
Table 2. Streamflow measurement results and corresponding time-series-interpolated streamflow results for the Ohio River near USGS streamgage number 03114306, upstream from Sardis, Ohio.

[UTC, Coordinated Universal Time; COV, coefficient of variation; RMSE, root-mean-square error; $\mathrm{ft}^{3} / \mathrm{s}$, cubic feet per second; \%, percent]

\begin{tabular}{|c|c|c|c|c|c|c|c|c|c|c|c|c|c|c|c|c|}
\hline \multirow{4}{*}{ Date } & \multirow{4}{*}{ UTC } & \multirow{2}{*}{\multicolumn{3}{|c|}{ USGS Measurement }} & \multicolumn{12}{|c|}{ Source of streamflow time series } \\
\hline & & & & & USGS 15 & ninute col & uted & USACE & 2 UTC moc & & USGS & our compu & & USGS & UTC com & ated \\
\hline & & \multirow{2}{*}{$\begin{array}{l}\text { Streamflow } \\
\quad\left(\mathrm{ft}^{3} / \mathrm{s}\right)\end{array}$} & \multirow{2}{*}{$\begin{array}{c}\text { Standard } \\
\text { deviation } \\
\left(\mathrm{ft}^{3} / \mathbf{s}\right)\end{array}$} & \multirow{2}{*}{$\begin{array}{l}\text { COV } \\
(\%)\end{array}$} & \multirow{2}{*}{$\begin{array}{l}\text { Inter- } \\
\text { polated } \\
\left(\mathrm{ft}^{3} / \mathbf{S}\right)\end{array}$} & \multicolumn{2}{|c|}{ Residual } & \multirow{2}{*}{$\begin{array}{l}\text { Inter- } \\
\text { polated } \\
\left(\mathrm{ft}^{3} / \mathbf{s}\right)\end{array}$} & \multicolumn{2}{|c|}{ Residual } & \multirow{2}{*}{$\begin{array}{c}\text { Inter- } \\
\text { polated } \\
\left(\mathrm{ft}^{3} / \mathrm{s}\right)\end{array}$} & \multicolumn{2}{|c|}{ Residual } & \multirow{2}{*}{$\begin{array}{c}\text { Inter- } \\
\text { polated } \\
\left(\mathrm{ft}^{3} / \mathbf{s}\right)\end{array}$} & \multicolumn{2}{|c|}{ Residual } \\
\hline & & & & & & $\left(\mathrm{ft}^{3} / \mathbf{s}\right)$ & $(\%)$ & & $\left(\mathrm{ft}^{3} / \mathrm{s}\right)$ & $(\%)$ & & $\left(\mathrm{ft}^{3} / \mathbf{s}\right)$ & $(\%)$ & & $\left(\mathrm{ft}^{3} / \mathbf{s}\right)$ & $(\%)$ \\
\hline $07 / 23 / 2013$ & $20: 28$ & 34,800 & 1,998 & 5.7 & 30,500 & 4,300 & 12.4 & 23,600 & 11,200 & 32.2 & 29,500 & 5,300 & 15.2 & 45,200 & $-10,400$ & -29.9 \\
\hline $11 / 15 / 2013$ & $17: 53$ & 26,900 & 58 & 0.2 & 27,900 & $-1,000$ & -3.7 & 24,700 & 2,200 & 8.2 & 27,900 & $-1,000$ & -3.7 & 27,100 & -200 & -0.7 \\
\hline $12 / 03 / 2013$ & 18:07 & 44,000 & 2,360 & 5.4 & 45,600 & $-1,600$ & -3.6 & 31,500 & 12,500 & 28.4 & 44,600 & -600 & -1.4 & 41,300 & 2,700 & 6.1 \\
\hline $02 / 21 / 2014$ & $17: 31$ & 96,800 & 2,149 & 2.2 & 93,500 & 3,300 & 3.4 & 62,700 & 34,100 & 35.2 & 97,700 & -900 & -0.9 & 88,700 & 8,100 & 8.4 \\
\hline $03 / 26 / 2014$ & $15: 46$ & 37,600 & 82 & 0.2 & 40,300 & $-2,700$ & -7.2 & 33,400 & 4,200 & 11.2 & 39,600 & $-2,000$ & -5.3 & 34,600 & 3,000 & 8.0 \\
\hline $04 / 09 / 2014$ & $15: 48$ & 87,100 & 739 & 0.8 & 85,500 & 1,600 & 1.8 & 90,700 & $-3,600$ & -4.1 & 87,300 & -200 & -0.2 & 89,200 & $-2,100$ & -2.4 \\
\hline $04 / 24 / 2014$ & $15: 24$ & 32,900 & 261 & 0.8 & 33,700 & -800 & -2.4 & 30,500 & 2,400 & 7.3 & 34,200 & $-1,300$ & -4.0 & 36,500 & $-3,600$ & -10.9 \\
\hline $05 / 01 / 2014$ & $17: 21$ & 82,600 & 3,501 & 4.2 & 82,700 & -100 & -0.1 & 61,100 & 21,500 & 26.0 & 84,700 & $-2,100$ & -2.5 & 80,400 & 2,200 & 2.7 \\
\hline 05/16/2014 & 18:06 & 143,000 & 1,630 & 1.1 & 132,000 & 11,000 & 7.7 & 125,000 & 18,000 & 12.6 & 132,000 & 11,000 & 7.7 & 127,000 & 16,000 & 11.2 \\
\hline $05 / 27 / 2014$ & $17: 04$ & 59,800 & 70 & 0.1 & 59,700 & 100 & 0.2 & 59,000 & 800 & 1.3 & 59,700 & 100 & 0.2 & 59,700 & 100 & 0.2 \\
\hline $06 / 03 / 2014$ & $16: 44$ & 28,500 & 577 & 2.0 & 31,000 & $-2,500$ & -8.8 & 20,200 & 8,300 & 29.1 & 32,600 & $-4,100$ & -14.4 & 22,500 & 6,000 & 21.1 \\
\hline Maximum & & 143,000 & & & 132,000 & 11,000 & 12.4 & 125,000 & 34,100 & 35.2 & 132,000 & 11,000 & 15.2 & 127,000 & 16,000 & 21.1 \\
\hline Minimum & & 26,900 & & & 27,900 & $-2,700$ & -8.8 & 20,200 & $-3,600$ & -4.1 & 27,900 & $-4,100$ & -14.4 & 22,500 & $-10,400$ & -29.9 \\
\hline Mean & & 61,273 & & & 60,218 & 1,055 & 0.0 & 51,127 & 10,145 & 17.0 & 60,891 & 382 & -0.8 & 59,291 & 1,982 & 1.2 \\
\hline Median & & 44,000 & & & 45,600 & -100 & -0.1 & 33,400 & 8,300 & 12.6 & 44,600 & -900 & -1.4 & 45,200 & 2,200 & 2.7 \\
\hline Mean absolute & & & & & & 2,636 & 4.7 & & 10,800 & 17.8 & & 2,600 & 5.0 & & 4,945 & 9.2 \\
\hline RMSE & & & & & & 3,939 & & & 14,590 & & & 4,025 & & & 6,771 & \\
\hline
\end{tabular}


Table 3. Streamflow measurement results and corresponding traveltime-corrected time-series-interpolated streamflow results for the Ohio River about 1.5 miles downstream from Hannibal Lock and Dam.

[UTC, Coordinated Universal Time; COV, coefficient of variation; RMSE, root-mean-square error; $\mathrm{ft} / \mathrm{s}$, feet per second; $\mathrm{ft}^{3} \mathrm{~s}$, cubic feet per second; $\%$, percent]

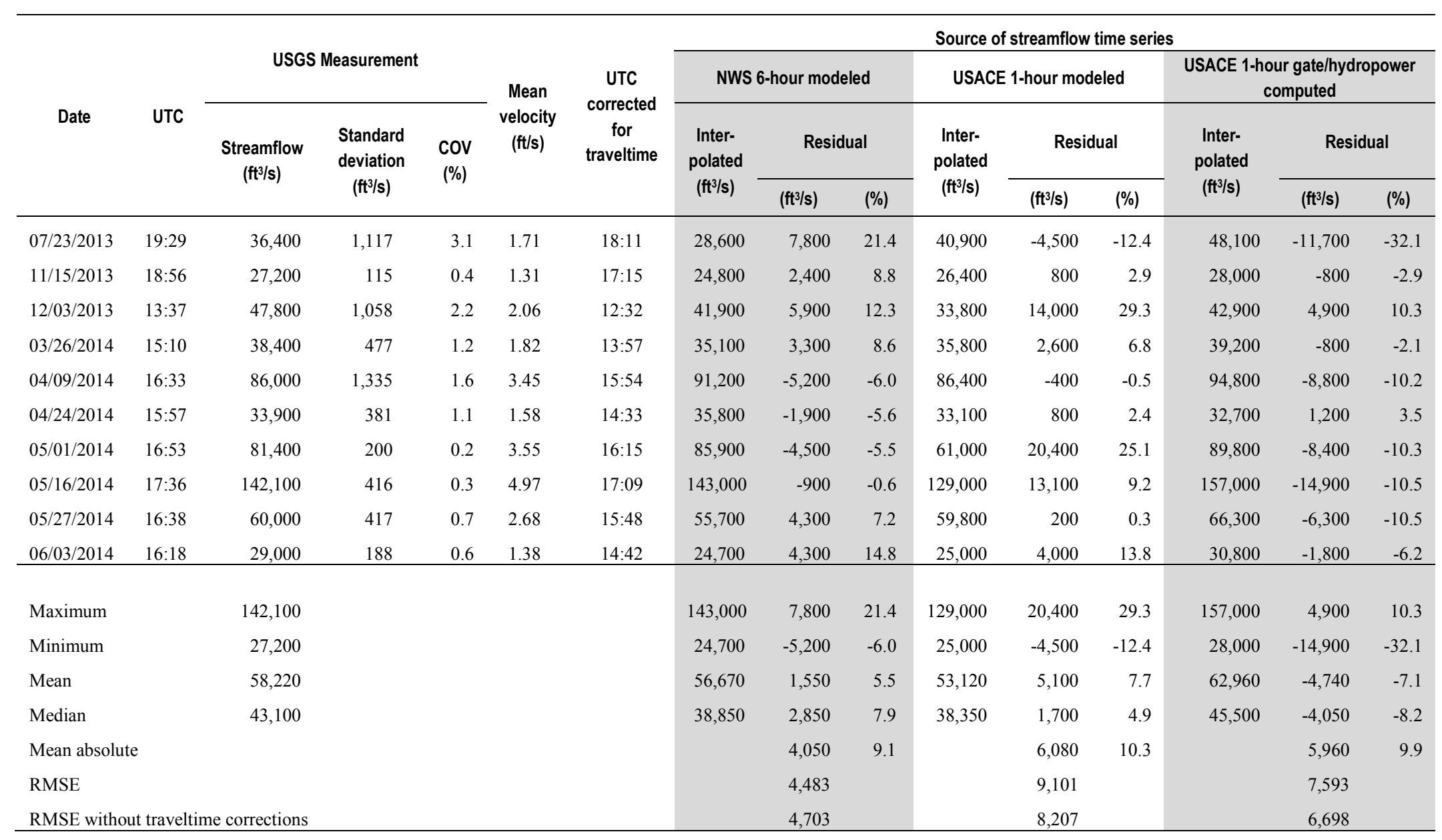


Also listed are the mean absolute residuals (the arithmetic mean of the absolute values of residuals) and the root-mean-square error (RMSE) computed as follows:

$$
\text { RMSE }=\sqrt{\frac{\sum_{i=1}^{n} e_{i}^{2}}{n}}
$$

where $e_{i}$ is the $i$ th residual and $n$ is the number of residuals.

The RMSEs for the Hannibal Lock and Dam location are reported in Table 3 on the basis of interpolations made with and without corrections for traveltime. Ultimately, the traveltime corrections had relatively minor effect, resulting in changes to the RMSEs ranging from -4.7 to 13.4 percent as compared to the non-time-corrected RMSEs, and did not change the rank order of the RMSE results for the base time series. To facilitate further discussion, traveltime-corrected interpolated streamflow values for the Hannibal Lock and Dam location will be referred to simply as "interpolated streamflow values" unless stated otherwise.

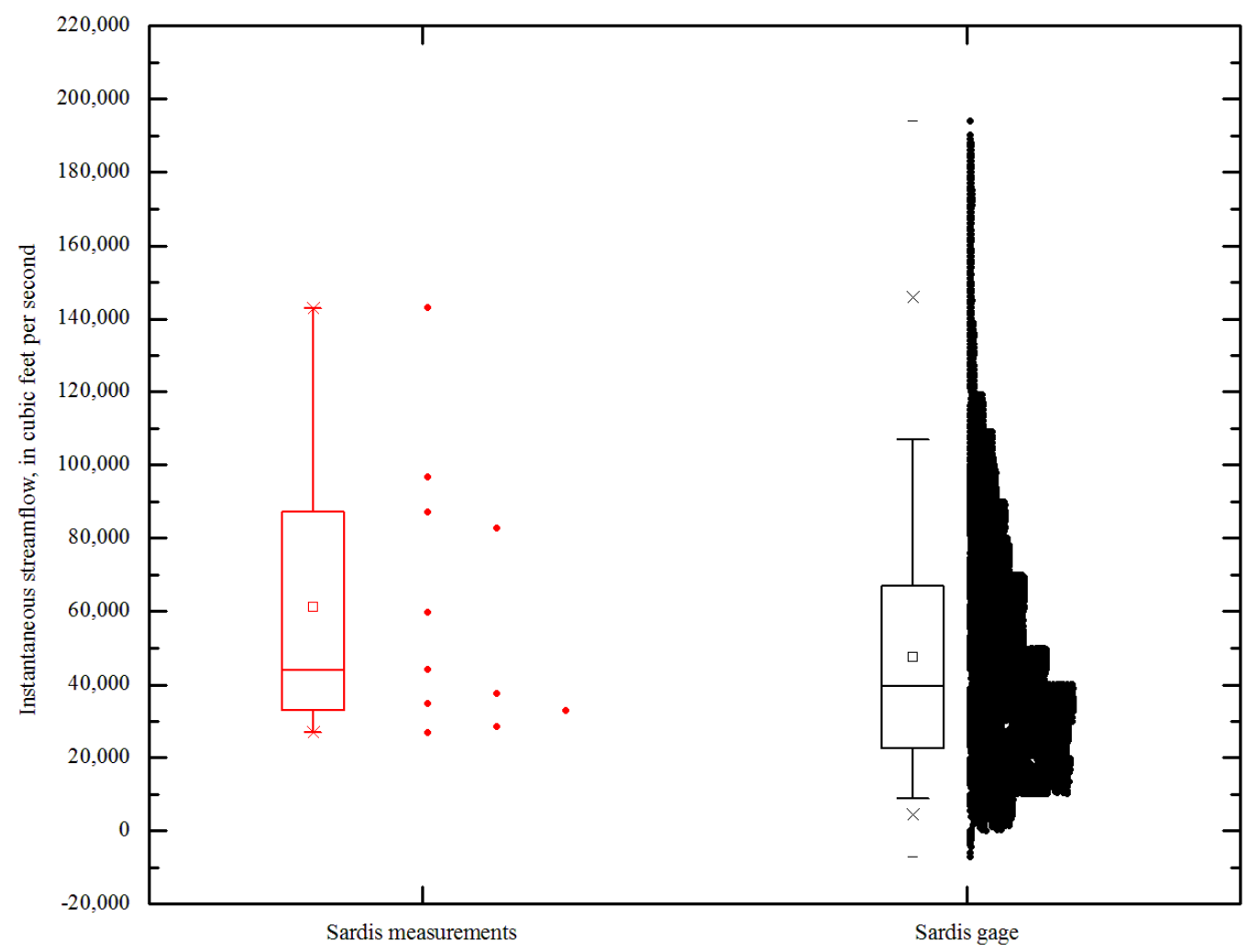

Figure 2. Boxplots and data plots (binned data, arbitrary horizontal offset) showing the distribution of instantaneous streamflows measured and computed for the Ohio River above Sardis, Ohio (streamgage number 03114306), July 1, 2013, to June 30, 2014.

Side-by-side boxplots and data plots (Figure 2) were prepared showing the distribution of instantaneous streamflows measured at the Sardis gage and the 15-minute streamflow time series computed by the USGS for the Sardis gage. The plots show that no measurements were made at streamflows less than the 25th percentile of computed streamflows; however, the measurements that 
were made provide a moderately reasonable sampling of the higher percentiles of computed streamflows. The unfortunate lack of low-flow measurements resulted from measurement-boat availability issues during the low-flow period.

Scatterplots (Figure 3-Figure 7) were prepared to facilitate evaluation of how well modeled and computed streamflows compared to the measured streamflows. Measured streamflow values are plotted on the $x$-axis and the corresponding interpolated modeled/computed streamflow values are plotted on the $y$-axis. Bars are plotted extending \pm 2 standard deviations (determined from streamflows measured for two transects) from measured streamflows. A one-to-one line is shown on each scatterplot. If the measured streamflow and the corresponding interpolated modeled/computed streamflow are equal, the point plotted for that data pair will lie on the one-to-one line. Points that plot off the one-to-one line but whose bars overlap the line are more likely to reflect deviations due to measurement error/uncertainty than points that lie further away from the line.

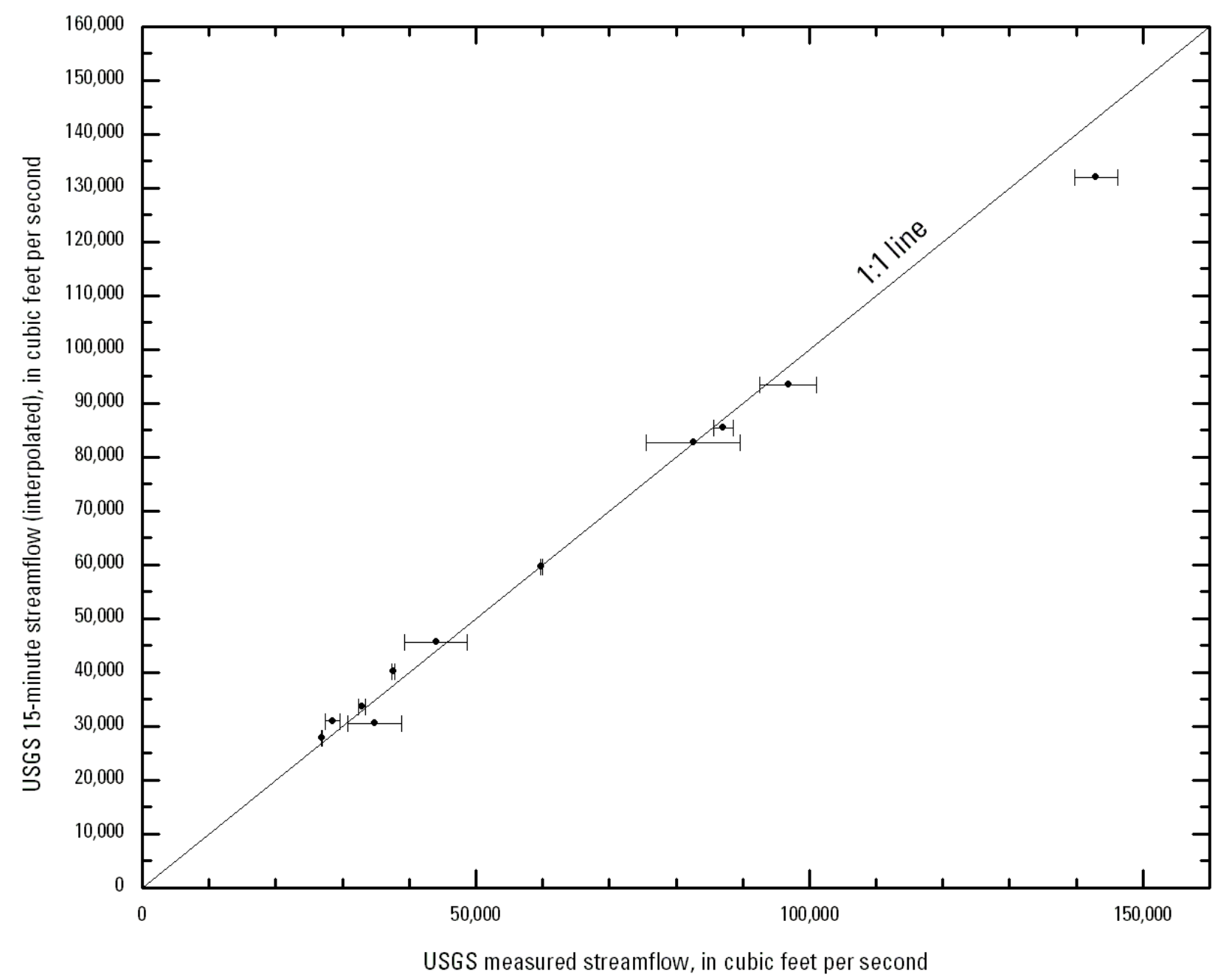

Figure 3. Scatterplot of USGS measured streamflows and corresponding streamflows interpolated from 15minute streamflow time series computed for the USGS streamgage on the Ohio River above Sardis, Ohio (station number 03114306) (bars extend \pm 2 standard deviations from the mean of streamflows computed for 2 transects). 


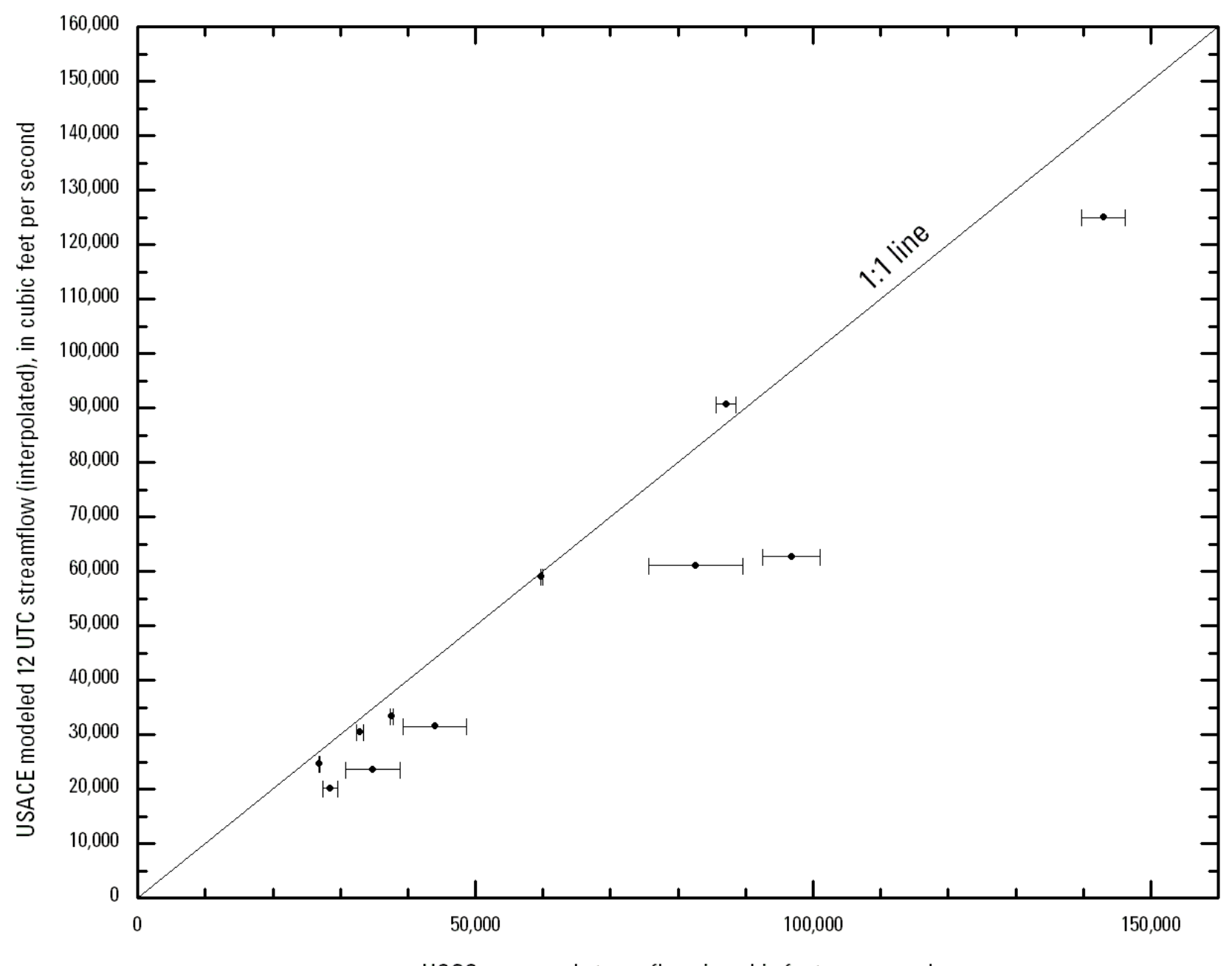

USGS measured streamflow, in cubic feet per second

Figure 4. Scatterplot of USGS measured streamflows and corresponding streamflows interpolated from USACE modeled 12 UTC streamflow time series for Ohio River mile 129.5 near the USGS streamgage on the Ohio River above Sardis, Ohio (station number 03114306) (bars extend \pm 2 standard deviations from the mean of streamflows computed for 2 transects).

Scatterplots (Figure 3 and Figure 4) were prepared to facilitate comparisons between the measured streamflows at the Sardis gage and streamflows interpolated from USGS computed 15-minute streamflows and USACE 12 UTC modeled streamflows, respectively. It is apparent from these plots that the streamflows interpolated from USGS computed 15-minute time-series data (hereafter referred to as USGS 15-minute time-series data) typically lie much closer to the one-to-one line than do the streamflows interpolated from the USACE 12 UTC modeled time-series data. In fact, on the basis of data in Table 2, the RMSE was about 3.7 times larger for streamflows interpolated from USACE 12 UTC modeled time-series data than for the streamflows interpolated from USGS 15-minute time-series data, and the mean absolute residual was about 4.1 times larger for streamflows interpolated from USACE 12-UTC modeled time-series data than for streamflows interpolated from USGS 15-minute time-series data. These results are not surprising given that the USACE streamflows were determined by interpolation from once-daily time-series data, whereas the USGS 15-minute streamflows were 
interpolated from 15-minute time-series data. To permit more equal comparisons, the base USGS 15minute time-series data were downsampled (sampled to a time step coarser than that of the base time series) to create both an hourly time series of instantaneous streamflows and a once-daily time series of 12 UTC instantaneous streamflows. These downsampled time series were then used to interpolate streamflows at the times of the USGS streamflow measurements. The columns labeled "USGS 1-hour streamflow" and "USGS 12 UTC streamflow" in Table 2 show those interpolated streamflows as well as their respective residuals and summary statistics. Even after downsampling to once-daily values, the RMSE and the mean absolute residual were both more than 2.1 times larger for USACE 12 UTC modeled streamflows than for the USGS 12 UTC streamflows.

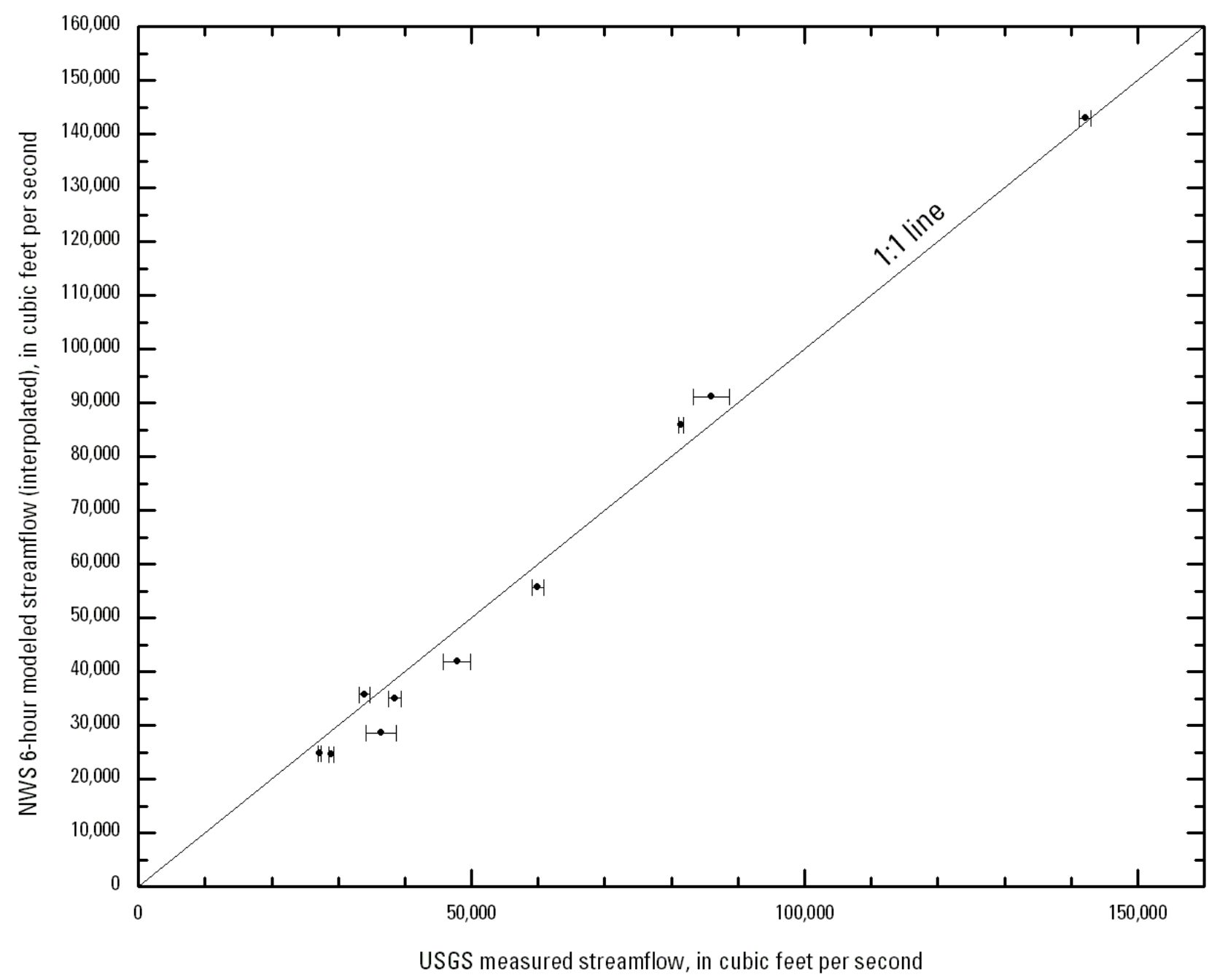

Figure 5. Scatterplot of USGS measured streamflows for the Ohio River approximately 1.5 miles downstream from Hannibal Lock and Dam and corresponding traveltime-corrected streamflows interpolated from NWS 6-hour modeled streamflow time series for the Ohio River at Hannibal Lock and Dam (bars extend \pm 2 standard deviations from the mean of streamflows computed for 2 transects). 


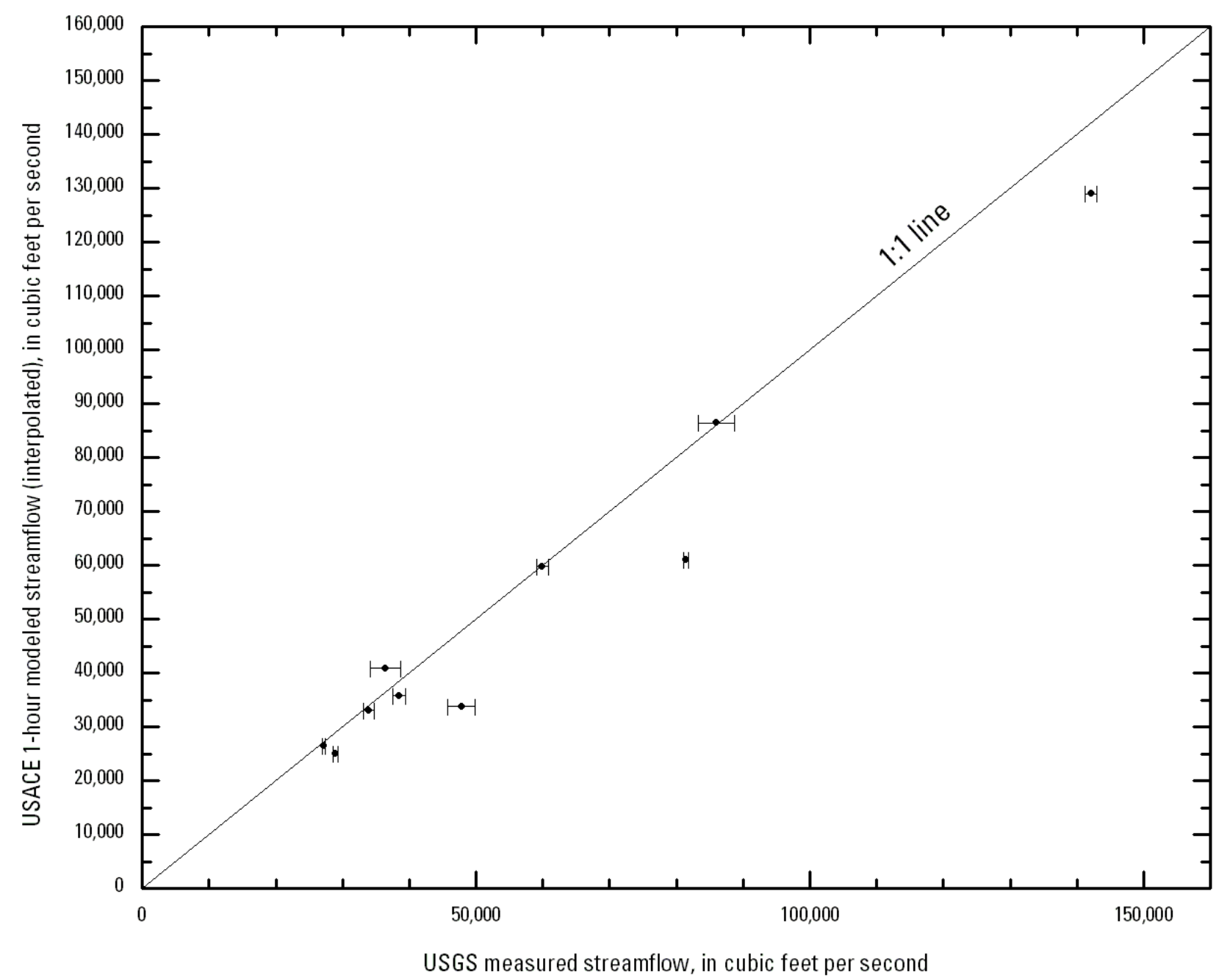

Figure 6. Scatterplot of USGS measured streamflows for the Ohio River approximately 1.5 miles downstream from Hannibal Lock and Dam and corresponding traveltime-corrected streamflows interpolated from USACE 1-hour modeled streamflow time series for the Ohio River at Hannibal Lock and Dam (bars extend \pm 2 standard deviations from the mean of streamflows computed for 2 transects). 


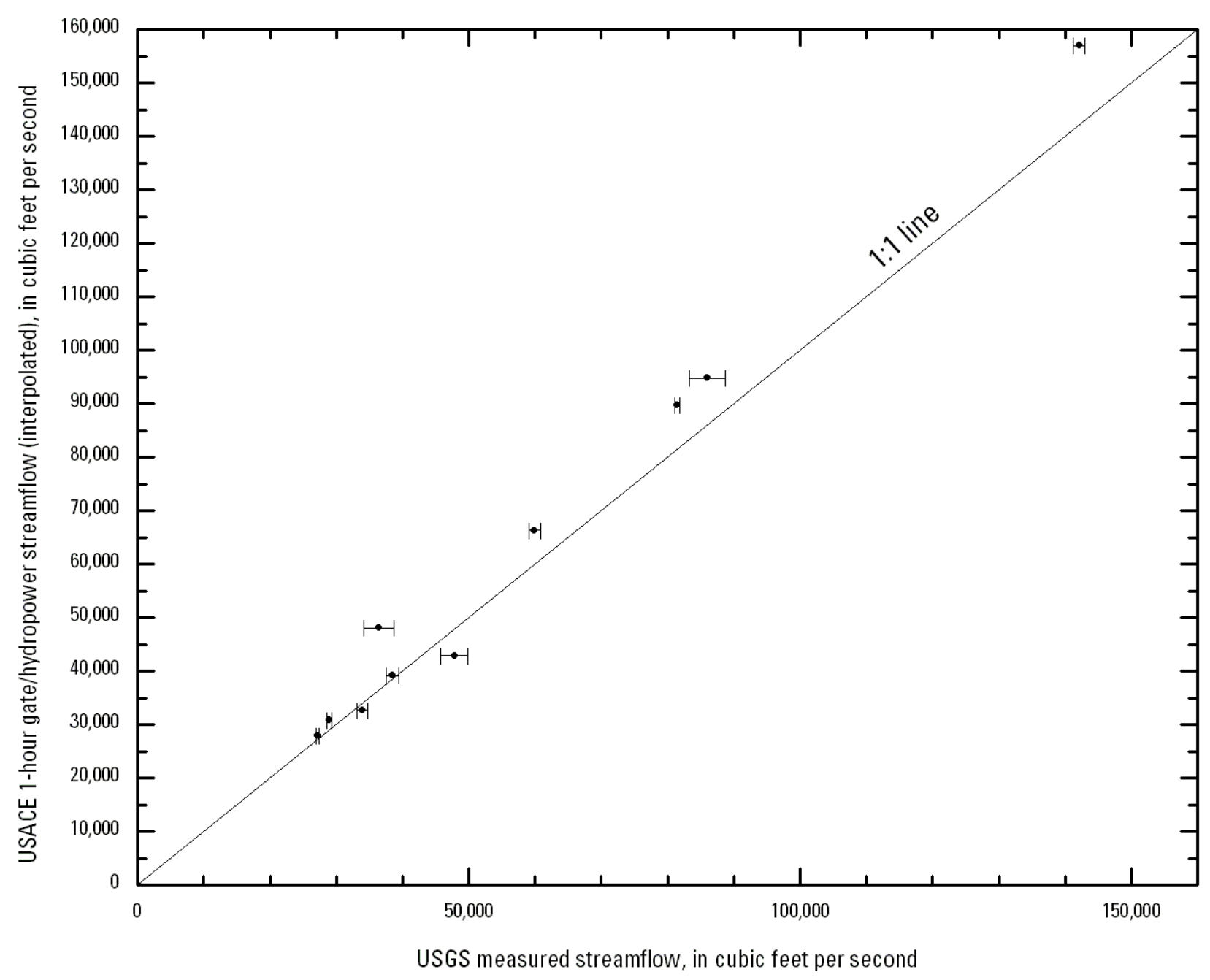

Figure 7. Scatterplot of USGS measured streamflows for the Ohio River approximately 1.5 miles downstream from Hannibal Lock and Dam and corresponding traveltime-corrected streamflows interpolated from USACE 1-hour streamflow time series determined from gate-opening ratings and hydropower releases for the Ohio River at Hannibal Lock and Dam (bars extend \pm 2 standard deviations from the mean of streamflows computed for 2 transects).

Scatterplots (Figure 5-Figure 7) were prepared to facilitate comparisons between the USGS measured streamflows at the Hannibal Lock and Dam location and interpolated NWS and USACE modeled/computed streamflows. The interpolated NWS 6-hour modeled streamflows showed better agreement with the measured streamflows than did streamflows determined from either of the USACE hourly time series. On the basis of data in Table 3, the RMSE for the interpolated computed and modeled USACE 1-hour streamflows ranged from about 1.7 to 2.0 times the RMSE of the interpolated NWS 6-hour modeled streamflows and mean absolute residuals were both about 1.5 times the mean absolute residual of the interpolated NWS 6-hour modeled streamflows. The better agreement of the NWS modeled 6-hour streamflows with the measured streamflows is somewhat surprising given the coarser time scale of the NWS time-series data as compared to the USACE time-series data. 
Overall, streamflows interpolated from the USGS 15-minute time-series data had the smallest $\operatorname{RMSE}\left(3,939 \mathrm{ft}^{3} / \mathrm{s}\right)$ and the second smallest mean absolute residual $\left(2,636 \mathrm{ft}^{3} / \mathrm{s}\right)$ (Table 4), whereas streamflows interpolated from the USACE 12 UTC time series had the largest RMSE $\left(14,590 \mathrm{ft}^{3} / \mathrm{s}\right)$ and the largest mean absolute residual $\left(10,800 \mathrm{ft}^{3} / \mathrm{s}\right)$. Streamflows interpolated from the USGS downsampled 1-hour time series had the second smallest RMSE $\left(4,025 \mathrm{ft}^{3} / \mathrm{s}\right)$ and the smallest mean absolute residual $\left(2,600 \mathrm{ft}^{3} / \mathrm{s}\right)$. Interestingly, streamflows interpolated from the NWS 6-hour modeled time series had the third smallest RMSE $\left(4,483 \mathrm{ft}^{3} / \mathrm{s}\right)$ and mean absolute residual $\left(4,050 \mathrm{ft}^{3} / \mathrm{s}\right)$ in spite of being determined from a time series with a coarser time step than the USACE 1-hour modeled and computed time series.

Table 4. Summary and rankings of root-mean-square errors and mean absolute residuals for streamflows interpolated from modeled and computed streamflow time series.

[RMSE, root-mean-square error; $\mathrm{ft}^{3} / \mathrm{s}$, cubic feet per second; \%, percent; rank is ascending sort order]

\begin{tabular}{|c|c|c|c|c|c|c|c|}
\hline \multirow{2}{*}{ Location } & \multirow{2}{*}{ Streamflow time series } & \multicolumn{2}{|c|}{ RMSE } & \multicolumn{4}{|c|}{ Mean absolute residual } \\
\hline & & $\mathrm{ft}^{3} / \mathrm{s}$ & Rank & $\mathrm{ft}^{3 / \mathrm{s}}$ & Rank & $\%$ & Rank \\
\hline \multirow{4}{*}{$\begin{array}{c}\text { Sardis } \\
\text { gage }\end{array}$} & USGS 15-minute computed & 3,939 & 1 & 2,636 & 2 & 4.7 & 1 \\
\hline & USACE 12 UTC modeled & 14,590 & 7 & 10,800 & 7 & 17.8 & 7 \\
\hline & USGS 1-hour (downsampled) & 4,025 & 2 & 2,600 & 1 & 5.0 & 2 \\
\hline & USGS 12 UTC (downsampled) & 6,771 & 4 & 4,945 & 4 & 9.2 & 4 \\
\hline \multirow{3}{*}{$\begin{array}{c}\text { Hannibal } \\
\text { Lock and } \\
\text { Dam }\end{array}$} & NWS 6-hour modeled & 4,483 & 3 & 4,050 & 3 & 9.1 & 3 \\
\hline & USACE 1-hour modeled & 9,101 & 6 & 6,080 & 6 & 10.3 & 6 \\
\hline & USACE 1-hour gate/hydropower & 7,593 & 5 & 5,690 & 5 & 9.9 & 5 \\
\hline
\end{tabular}

Streamflows measured at the Sardis gage and at the Hannibal Lock and Dam measurement locations were plotted versus residuals, expressed as a percentage of the measured streamflows, of corresponding interpolated time-series streamflow values (Figure 8 and Figure 9). These percent residuals will be hereafter referred to as "PRs." At the Sardis gage, PRs for streamflows interpolated from the USGS 15-minute time-series data ranged from -8.8 to +12.4 percent and tended to be negative at lower streamflows and positive at higher streamflows (Figure 8). Furthermore, when the result for the outlier on July 23, 2013, was excluded, the trend in PRs for streamflows interpolated from the USGS 15-minute time-series data was abnormally linear (Pearson's $r=0.92$ ). By comparison, PRs for the interpolated USACE modeled 12 UTC streamflows did not display similar linear tendencies but instead were nearly all positive (indicating that the modeled value was less than the measured value) and usually were much greater in absolute magnitude than PRs for corresponding streamflows interpolated from the USGS 15-minute time-series data. At the Hannibal Lock and Dam measurement location, PRs for streamflows interpolated from the NWS and USACE modeled/computed time series ranged from -32.1 to +29.3 percent. PRs for streamflows interpolated from the USACE gate/hydropower hourly time-series data were predominately negative (indicating that the modeled value was greater than the measured value) and were consistently so for streamflows greater than about $50,000 \mathrm{ft}^{3} / \mathrm{s}$. PRs for the NWS modeled 6-hour streamflows were predominately positive (indicating that the modeled value was less than the measured value) for measured streamflows less than or equal to $60,000 \mathrm{ft}^{3} / \mathrm{s}$ and consistently negative for streamflows greater than $60,000 \mathrm{ft}^{3} / \mathrm{s}$. PRs for the USACE 1-hour modeled streamflows were predominately positive and included the two largest positive PRs and the second 
negative PR for the Hannibal Lock and Dam measurement location. Ultimately, results for each of the time series exhibited some anomaly, possibly indicating the need and (or) potential for improvement in the streamflow computational/modeling processes.

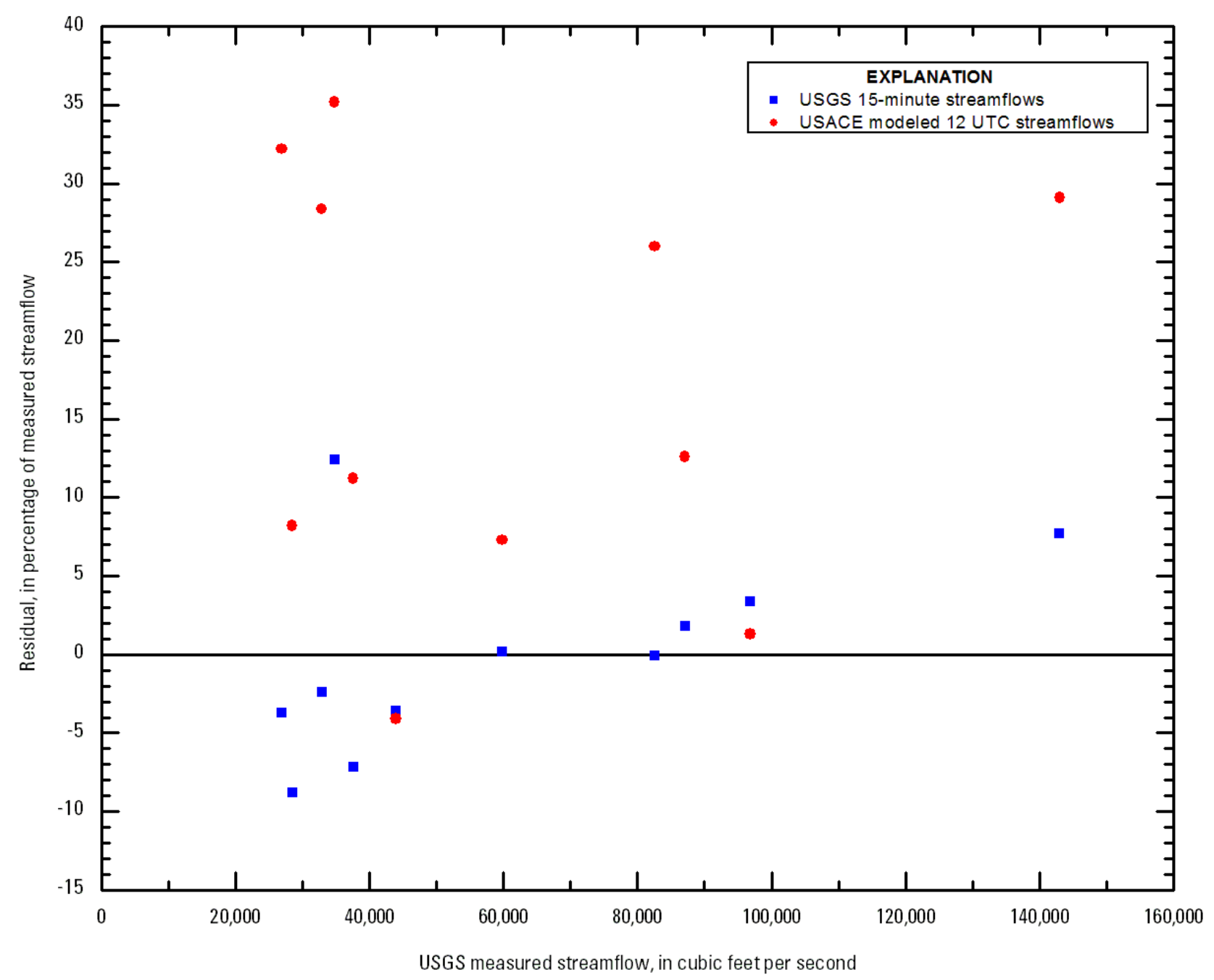

Figure 8. Scatterplot of streamflows measured at the Sardis gage versus the residuals for the corresponding interpolated modeled/computed time-series streamflows expressed as a percentage of the measured streamflows. 


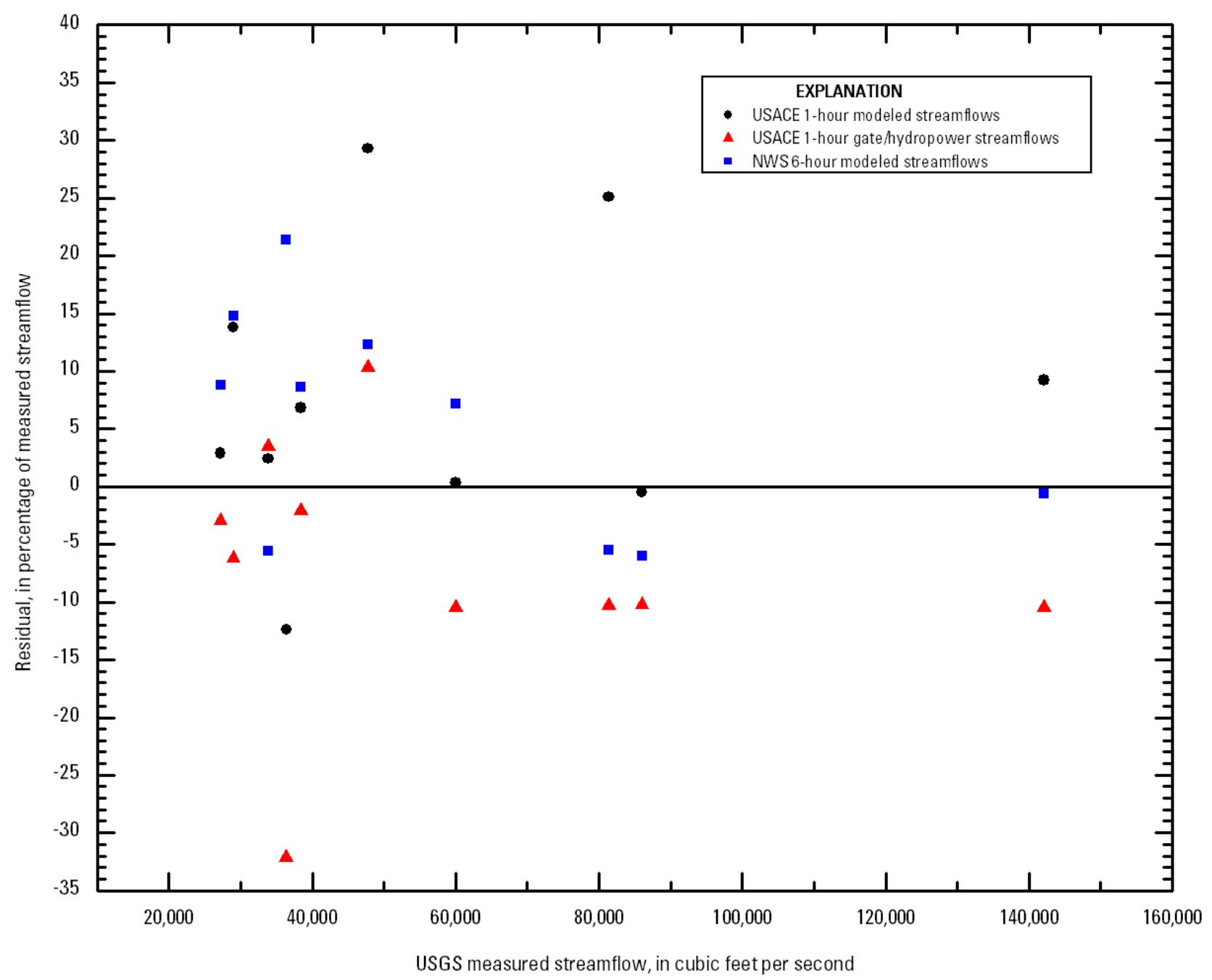

Figure 9. Scatterplot of streamflows measured at the Hannibal Lock and Dam measurement location versus the residuals for the corresponding traveltime-corrected interpolated modeled/computed time-series streamflows expressed as a percentage of the measured streamflows.

Streamflow hydrographs were plotted from modeled/computed time series for both Sardis gage location (Figure 10) and the Ohio River at Hannibal Lock and Dam (Figure 11). For the Sardis gage location, the hydrographs of USGS computed 15-minute streamflows and USACE modeled 12 UTC streamflows generally compare reasonably well. The hydrograph of the USACE modeled 12 UTC streamflows is appreciably less erratic than the hydrograph of USGS computed 15-minute streamflows. This is not unexpected given that the USACE modeled 12 UTC streamflows do not show intraday variability in streamflows because of the daily time step. The daily time step also may explain why the USACE modeled 12 UTC streamflows frequently do not reach the local highs and lows (including periods of negative streamflow, a phenomenon seen only in USGS computed streamflow time series) in streamflow that are reflected in the USGS computed 15-minute streamflows. The hydrograph of USGS computed 15-minute streamflows has gaps reflecting periods of missing record. Because equipment failure or other problems that result in loss of data can occur at gaging stations, it seems prudent that (at 
a minimum) models be maintained as a backup source of streamflow data even if the data that they provide may be less accurate than gage-based data.

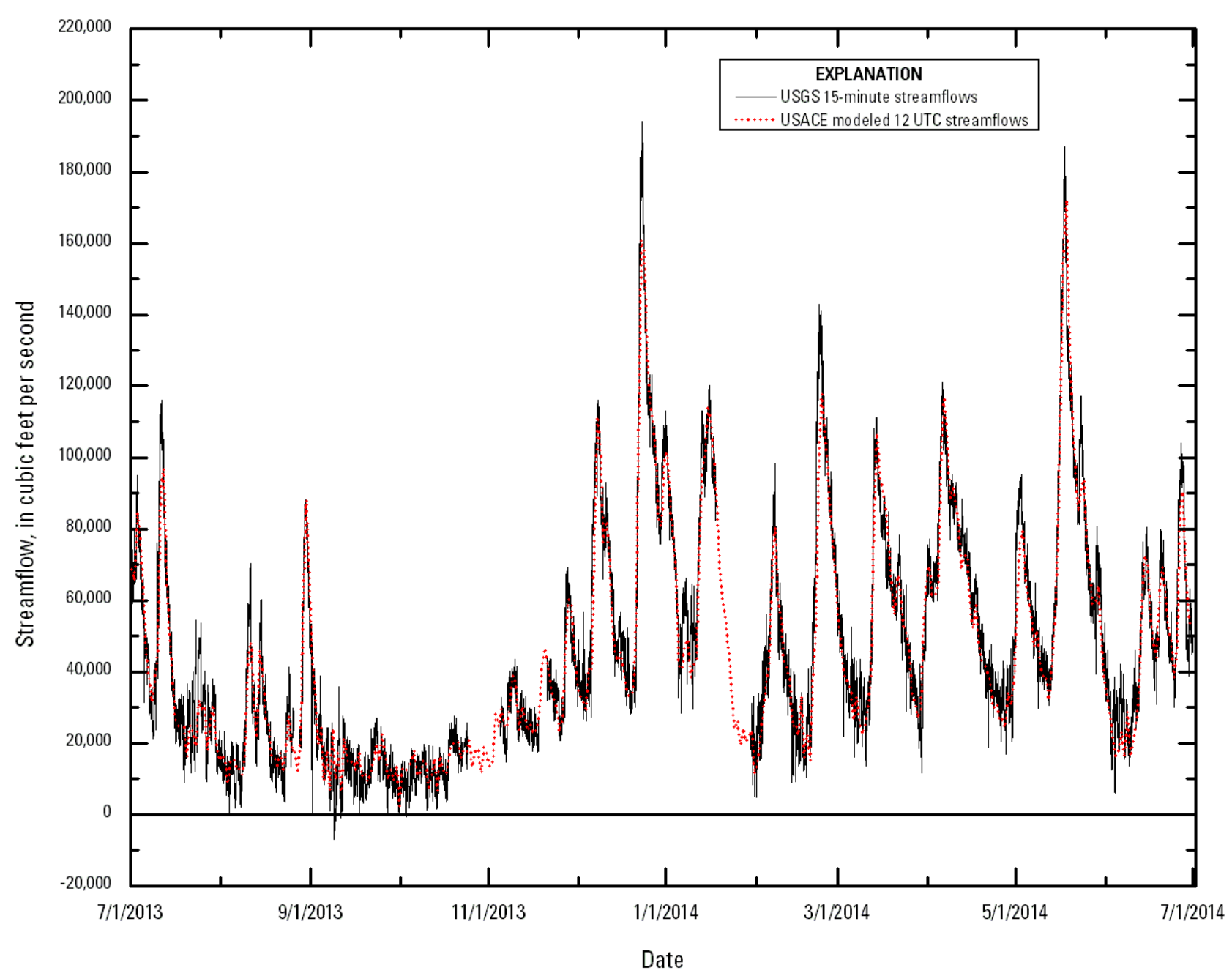

Figure 10. Modeled/computed streamflow hydrographs for the Ohio River above Sardis, Ohio (station number 03114306), July 1, 2013, to June 30, 2014. 


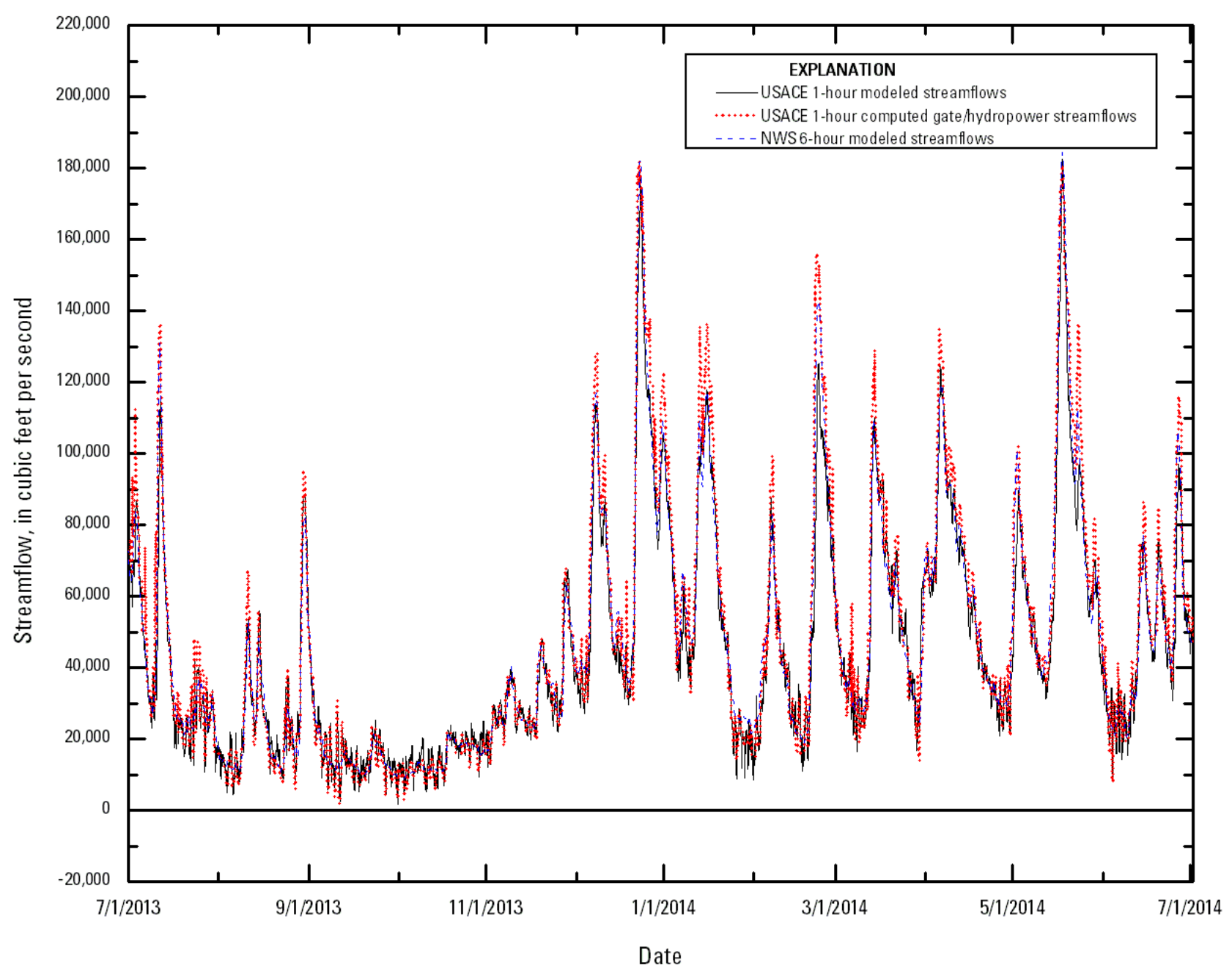

Figure 11. Modeled/computed streamflow hydrographs for the Ohio River at Hannibal Lock and Dam, July 1 , 2013, to June 30, 2014.

For the Hannibal Lock and Dam, the hydrographs of the USACE and NWS modeled/computed streamflow generally compared well except that the USACE gate/hydropower hourly streamflows frequently peaked at streamflow rates appreciably higher than the corresponding USACE and NWS modeled streamflows (Figure 11). In fact, several of the USACE gate/hydropower hourly streamflow peaks also were appreciably larger than corresponding peaks computed for the downstream Sardis gage.

\section{Limitations}

The analyses described in this report were made on the basis of a relatively small number of measurements that do not span the entire range of modeled/computed streamflows. The results should not be construed as being definitive or as being representative of computational or modeling results in general. 


\section{Summary}

Between July 2013 and June 2014, the U.S. Geological Survey (USGS) made 10 streamflow measurements on the Ohio River about 1.5 miles (mi) downstream from the Hannibal Lock and Dam, near Hannibal, Ohio, and 11 streamflow measurements near the USGS streamgage located approximately $2.4 \mathrm{mi}$ upstream from Sardis, Ohio. The measurements results were used to assess the accuracy of modeled/computed streamflow time series created by the USGS, U.S. Army Corps of Engineers (USACE), and National Weather Service (NWS) for the Ohio River at the Hannibal Lock and Dam and (or) near the USGS streamgage. Modeled/computed Ohio River streamflow time-series data were obtained for the time period extending from July 1, 2013, to June 30, 2014. Time-series data for the Sardis gage location were available only from the USGS and USACE, and time-series data for the Hannibal Lock and Dam location were available only from the USACE and NWS.

Side-by-side boxplots and data plots were prepared to show the distribution of instantaneous streamflows measured at the Sardis gage and 15-minute streamflow time-series data computed by the USGS for the Sardis gage. Those plots showed that no measurements were made at streamflows less than about the 25th percentile of computed streamflows; however, the measurements that were made provided a moderately reasonable sampling of the higher percentiles of computed streamflows.

To facilitate comparisons between streamflow measurement results and time-series data, streamflows corresponding to the times of the streamflow measurements were computed from the timeseries data by interpolating linearly in time between time-series values that bracketed the times of measurements. Prior to doing interpolations, measurement times for the Hannibal Lock and Dam location were adjusted to account for traveltime from Hannibal Lock and Dam (the location corresponding to the modeled/computed time-series data) to the measurement location $1.5 \mathrm{mi}$ downstream. Measured and interpolated streamflows were tabulated along with residuals and selected summary statistics.

Scatterplots were prepared to facilitate evaluation of how well interpolated modeled/computed streamflows compared to the measured streamflows. For the Sardis gage location, streamflows interpolated from USGS 15-minute time-series data typically plotted much closer to the one-to-one line than did the interpolated USACE 12:00 Coordinated Universal Time (12 UTC) modeled streamflows. Those results likely are due in part to the finer time step of the USGS time-series data. To permit more equal comparisons, the USGS 15-minute time-series data were downsampled to create an hourly time series of instantaneous streamflows and a once-daily time series of 12 UTC instantaneous streamflows. These downsampled time series were then used to interpolate streamflows corresponding to the times of the USGS streamflow measurements. Even after downsampling to once-daily values, the root-meansquare error (RMSE) and the mean absolute residual were both more than 2.1 times larger for USACE 12 UTC modeled streamflows than for the USGS 12 UTC streamflows.

For the Hannibal Lock and Dam location, the interpolated NWS modeled 6-hour streamflows showed better agreement with the measured streamflows than did streamflows interpolated from either of the USACE hourly time series. The RMSE for the interpolated USACE streamflows ranged from about 1.7 to 2.0 times the RMSE of the interpolated NWS 6-hour modeled streamflows and mean absolute residuals were both about 1.5 times the mean absolute residual of the interpolated NWS 6-hour modeled streamflows.

Overall, streamflows interpolated from the USGS 15-minute time-series data had the smallest RMSE and the second smallest mean absolute residual, whereas streamflows interpolated from the USACE 12 UTC time series had the largest RMSE and the largest mean absolute residual. Streamflows interpolated from the USGS downsampled 1-hour time series had the second smallest RMSE and the smallest mean absolute residual. Somewhat surprisingly, streamflows interpolated from the NWS 6- 
hour model time series had the third smallest RMSE and mean absolute residual in spite of being determined from a time series with a coarser time step than the USACE 1-hour modeled and computed time series.

Measured streamflows at the Sardis gage and at the Hannibal Lock and Dam measurement location were plotted versus percent residuals (PRs) of the corresponding interpolated time-series streamflow values. At the Sardis gage, PRs for streamflows interpolated from the USGS 15-minute time-series data ranged from -8.8 to +12.4 percent and tended to vary in a fairly linear fashion from negative at lower streamflows to positive at higher streamflows. PRs for the interpolated USACE modeled 12 UTC streamflows did not display similar linear tendencies but instead were nearly all positive and usually were much greater in absolute magnitude than PRs for corresponding streamflows interpolated from the USGS 15-minute time-series data. At the Hannibal Lock and Dam measurement location, PRs for streamflows interpolated from the NWS and USACE modeled/computed time series ranged from -32.1 to +29.3 percent. PRs for streamflows interpolated from the USACE gate/hydropower hourly time-series data were predominately negative and were consistently so for streamflows greater than about 50,000 cubic feet per second $\left(\mathrm{ft}^{3} / \mathrm{s}\right)$. PRs determined for the NWS modeled 6-hour streamflows were predominately positive for measured streamflows less than or equal to $60,000 \mathrm{ft}^{3} / \mathrm{s}$ and consistently negative for streamflows greater than $60,000 \mathrm{ft}^{3} / \mathrm{s}$. PRs for the USACE 1-hour modeled streamflows were predominately positive and included the two largest positive PRs and the second largest negative PR for the Hannibal Lock and Dam measurement location. Ultimately, results for each of the time series exhibited some anomaly, possibly indicating the need and (or) potential for improvement in the streamflow computational/modeling processes.

Streamflow hydrographs were plotted from modeled/computed time series for the Sardis gage and Hannibal Lock and Dam locations. In general, the time series at these two locations compared well. Some notable differences include the exclusive presence of short periods of negative streamflows in the USGS 15-minute time-series data for the Sardis gage location and the occurrence of several peak streamflows in the USACE gate/hydropower time series for the Hannibal Lock and Dam that were appreciably larger than corresponding peaks in the other time series, including those modeled/computed for the downstream Sardis gage.

\section{References Cited}

Burnash, R.J.C., 1995, The NWS River Forecast System-Catchment model, chap. 10 of Singh, V.P., ed., Computer models of watershed hydrology: Highlands Ranch, Colo., Water Resources Publications, p. 311-366.

Lee, D.H, and Wisbith, S.M., 2006, Modeling the Ohio River-Not just for floods anymore, in Proceedings of the Third Federal Interagency Hydrologic Modeling Conference, Reno, Nevada, April 2-6, 2006: Accessed December 30, 2014, at http://www.gcmrc.gov/library/reports/physical/Fine_Sed/8thFISC2006/3rdFIHMC/7E_Lee.pdf.

Levesque, V.A., and Oberg, K.A., 2012, Computing discharge using the index velocity method: U.S. Geological Survey Techniques and Methods, book 3, chap. A23, 148 p. (Also available at http://pubs.usgs.gov/tm/3a23/.)

Mueller, D.S., Wagner, C.R., Rehmel, M.S., Oberg, K.A., and Rainville, Francois, 2013, Measuring discharge with acoustic Doppler current profilers from a moving boat (ver. 2.0, December 2013): U.S. Geological Survey Techniques and Methods, book 3, chap. A22, 95 p., accessed December 29, 2014, at http://dx.doi.org/10.3133/tm3A22. 
National Weather Service (NWS), 2014a, Sacramento Soil Moisture Accounting (SAC-SMA) Model: National Weather Service, accessed December 29, 2014, at

http://www.nws.noaa.gov/oh/hrl/general/chps/Models/Sacramento_Soil_Moisture_Accounting.pdf

National Weather Service (NWS), 2014b, Lag and K Routing (Lag/K) Model: National Weather Service, accessed December 29, 2014, at http://www.nws.noaa.gov/oh/hrl/general/chps/Models/Lag and K Routing.pdf

National Weather Service (NWS), 2015, Tatum Coefficient Routing (TATUM) Model: National Weather Service, accessed March 10, 2015, athttp://www.nws.noaa.gov/oh/hrl/general/chps/Models/Tatum_Coefficient_Routing.pdf

Ohio River Valley Water Sanitation Commission (ORSANCO), 2014, River facts/conditions: ORSANCO Web page, accessed December 29, 2014, at http://www.orsanco.org/river-factsconditions. 
ISSN 2331-1258 (online)

http://dx.doi.org/10.3133/ofr20151058 